\title{
Textbook Evaluation: A Case Study of Cutting Edge
}

\author{
Mohd Nazim \\ Dept. of English, Najran University, Saudi Arabia
}

\begin{abstract}
This paper, in deviation from the traditional practices of textbook evaluation, reports the faculty members' evaluation of Cutting Edge, Student Book, KSA Third Edition Intermediate Level, by Sarah Cunningham \& Peter Moor, published by Pearson 2013 in terms of Language Development Skills, in general, and, Listening, Speaking, Reading, Writing, Grammar \& Vocabulary, and Style \& Appropriacy in particular. 20 EFL teachers participated in this mixed method approach of study who work at the Department of English Skills, Preparatory Year, Najran University, Saudi Arabia. A google form questionnaire, consisted of 57 numerically rated items \& open-ended questions under 7 domains, was created to elicit faculty members' responses. The validity of the questionnaire was examined by a group of experts in the textbook evaluation and content analysis. The analysis indicates that the respondents evaluated the textbook contents positively and the majority viewed them mostly suitable in terms of language skills, usage, and appropriacy. However, the researcher, based on the adverse comments like video material for listening, lack of specific strategies for conversation or other spoken activities, and hardly distinction between active and passive vocabulary under listening, speaking and grammar \& vocabulary domains, suggests that a latest EFL commercial textbook or series be reviewed which, potentially, will cover the space. To conclude, the researcher recommends developing authentic materials that are tailored to the needs and interests of the learners.
\end{abstract}

Index Terms - cutting edge, EFL teachers, textbook evaluation etc

\section{INTRODUCTION}

Textbooks guide teachers and students alike and have been a great resource in teaching and learning contexts. However, if not carefully analyzed, a textbook can have an adverse influence on teaching and learning environment. Crawford (2002) stated that when choosing classroom resources, practitioners should consider the concepts that underlying them to ensure that they contribute positively to the learning environment. When a textbook is first introduced, it should be thoroughly scrutinized to ensure that the content is appropriate for the classroom (Fredriksson and Olsson 2006). Textbook evaluation is not an easy task and therefore, evaluators must make several decisions while doing textbook evaluation (Abbasian \& Khajavi, 2011). Textbook selection can be approached in a variety of ways, although it is frequently done based on the educators' personal preferences and may be influenced by factors unrelated to education (Garinger, 2002). In EFL/ESL contexts, textbook evaluation is essential to evaluate the content of the textbook and to associate it with the teaching/learning conditions (Ahour, Towhidiyan, and Saeidi, 2014). Nunan (1991) points out that, "The way materials are organized and presented, as well as the types of content and activities, will help to shape the learner's view of language." Sheldon (1988) argues that the book should have an optimum density and mix of text and graphical material on each page. Good textbooks should be supplied with various activities and tasks that engage learners in the use of skills and processes related to specific language teaching objectives. Also, they should include variety of exercises that give students opportunities to practice and extend their language skills. Tomlinson (1998) relates tasks with learners' self-confidence. Richards (2001) elaborates that the tasks in the textbooks should be flexible and appeal to different styles and strategies and should not favor one type of learner over another. McDonough and Shaw (2003) argue that materials should enable the learners to see how the four skills (listening, speaking, reading and writing) can be used effectively in appropriate contexts. This study evaluates Cutting Edge, Student Book, KSA Third Edition Intermediate Level, written by Sarah Cunningham \& Peter Moor, published by Pearson 2013. In doing so, the researcher employed a questionnaire inspired by various checklists (Daoud, A.M., and Celce-Murcia, M. 1979; Byrd, 2001; Byrd \& Schuemann, 2014; Cunningworth, 1995; Littlejohn, 1998; Mann \& Copland, 2015; Mukundan \& Ahour, 2010), which is based on a set of general attributes that not only meet this research criteria, but also have enough flexibility to be used universally with some further modifications.

\section{REVIEW OF LITERATURE}

Many studies on textbook evaluation have been conducted around the world. In 2013, Sarem, Hamidi, and Mahmoudie evaluated a book of English for International Tourism adapting Daoud and Celce-Murcia checklist, conclude that the current book can be used as an acceptable textbook to teach to students who are interested in studying tourism. Birjandi and Alizadeh (2012) investigated the extent to which the Top Notch, Interchange, and English File 
series include critical thinking skills. Using a checklist based on Bloom's taxonomy, they opined that the books primarily tapped knowledge, comprehension, application, and the ability to form a community of thinkers.

Yasemin (2009) evaluates three English textbooks. Teachers and students took part in a 37-item textbook evaluation scheme to convey their thoughts on various aspects of the textbooks. In addition, interviews were done to understand more about how the textbooks were used. The data suggested that the three textbooks used by young learners were adequate to a certain level. The study advises that textbooks for young English learners be revised and/or designed. Riasati and Zare (2010) assessed the Interchange textbooks' overall instructional value and appropriateness from the perspective of Iranian EFL teachers. The findings revealed that most teachers agreed that the textbooks were useful and acceptable. Despite these benefits, several shortcomings were identified in this series, including a lack of supporting teaching resources, too many testing activities, and an insufficient number of teacher's handbooks among many. Rashidi and Kehtarfard (2014) use a needs analysis framework to report on the outcomes of a study that employed a needs analysis framework to evaluate an English textbook (the third-grade high school English book) that is used in all Iranian state high schools. The textbook evaluation found that, while all language skills and components were virtually equally significant to the majority of students, the textbook could not adequately support all of them at the same time. Hussin, Nimehchisalem, Kalajahi, and Yunus (2016) assessed how new vocabulary items are presented in three English language textbooks used in Malaysian secondary schools. The presentation of vocabulary items in the textbook was evaluated using a checklist by a group of carefully selected instructors $(n=5)$. The research revealed that the vocabulary presentation in the textbook lacks many aspects. The new vocabulary was taught using no specific approach. At the end of the textbook, there was no index to the new terminology. The results though indicated implications for all stakeholders including learners, teachers as well as textbook developers.

\section{METHODOLOGY}

\section{Participants}

For this study, 20 teachers who were teaching Cutting Edge participated in this study. The teachers had taught (at the intermediate level) this textbook for 2 years.

\section{Instrument}

For data collection from the participants, a google form questionnaire was used. The questionnaire had 57 numerically rated items \& open-ended questions under 7 domains.

Data Collection and Analysis

The researcher held a meeting and explained the nature and purpose of the study. After the meeting the google form questionnaire was emailed to the participants to respond electronically. The responses were downloaded, analyzed, and discussed.

\section{ANALYSIS \& DisCUSSION}

To report the outcome of the textbook evaluation, this paper analyzed the responses and comments. Following are the discussions and analysis at length. This is also to note that the researcher, in open ended questions, had selected only distinct comments/responses, both positive and adverse. Similar and repetitive comments/contexts had been deleted.

Language Development Skills (scale Q1)

i) Are all four skills adequately covered, keeping the course objectives and syllabus requirements in mind?

Language Development Skills

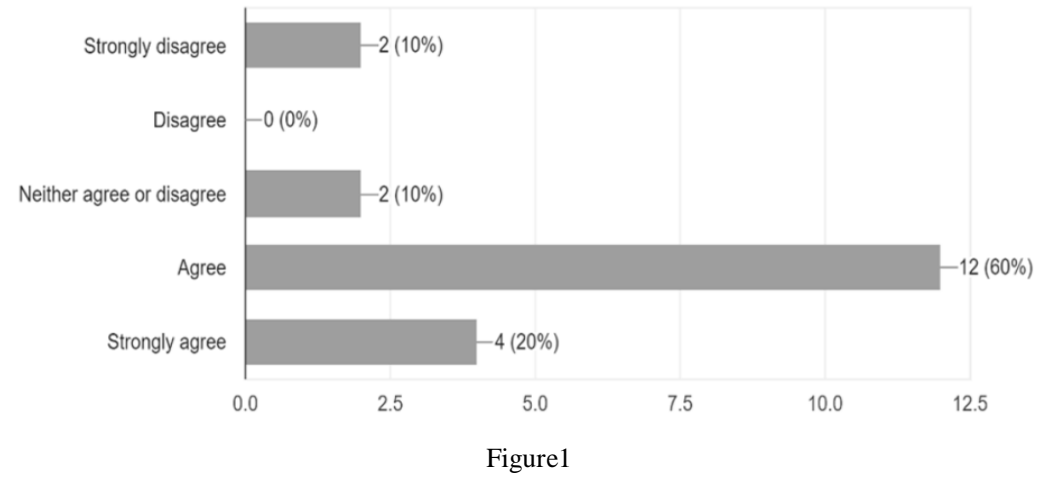

Figure 1 indicates that most of the participants (80\%) responded positively. Only 2 respondents (10\%) chose the adverse response followed by the same number (10\%) who decided to remain neutral. 


\section{Language Development Skills (Open ended Qs 2-4)}

\begin{tabular}{|c|c|c|}
\hline \multirow[t]{2}{*}{ Questions } & \multicolumn{2}{|l|}{ Responses } \\
\hline & positive & adverse \\
\hline $\begin{array}{l}\text { ii) Is practice in all four skills included? If so, } \\
\text { is it balanced? If not, which skills are } \\
\text { omitted, and why? }\end{array}$ & 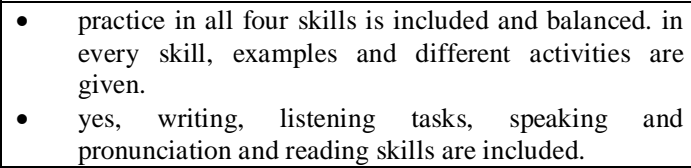 & $\begin{array}{l}\text { - it is included } \\
\text { but the } \\
\text { materials are } \\
\text { vague and } \\
\text { obscure. }\end{array}$ \\
\hline \multicolumn{3}{|c|}{ Analysis: The above responses revealed that the majority (80\%) responded in support of the motion. Only (20\%) reacted adversely. } \\
\hline $\begin{array}{l}\text { Does the material progress in terms of } \\
\text { complexity and difficulty, in line with the } \\
\text { grammatical and lexical progression of the } \\
\text { course? write examples: chapter/s and page } \\
\text { numbers }\end{array}$ & $\begin{array}{l}\text { - } \quad \text { "unit } 4 \text { page } 40 \text { - vocab and language focus } \\
\text { - } \quad \text { ex } 1 \text { grammar, chapter } 4 \text { page } 40 \\
\text { - } \quad \text { yes. eg ch-2 is more upgraded in terms of complexity } \\
\text { and difficulty than ch } 1 \text { and the pattern continues. } \\
\text { yes. }\end{array}$ & $\begin{array}{ll}\text { no, } & \text { the } \\
\text { objectives } & \text { are } \\
\text { not clear. } & \end{array}$ \\
\hline \multicolumn{3}{|c|}{$\begin{array}{l}\text { Analysis: The above responses revealed that the majority (70\%) support the material progression. } 6 \text { participants (30\%) responded } \\
\text { adversely too. }\end{array}$} \\
\hline $\begin{array}{l}\text { iv) Do the presentation and practice activities } \\
\text { include the integration of skills in realistic } \\
\text { contexts? } \\
\text { write examples: chapter/s and page numbers }\end{array}$ & $\begin{array}{ll}\text { - } & \text { "unit } 4 \text { p.36 3- page } 372 . b \text { unit } 5 \text { p49 .2 unit } 9 \text { p } 89 \\
\text { - } & \text { "yes. e.g. Jamal's party, ch 1, pg } 8 . " \\
\text { - } & \text { yes, ch\#4,36,37,38, and 39. grammar, reading, L/S are } \\
\text { integrated. } \\
\text { yes. there are practice activities catering to all the } 4 \\
\text { skills. eg. all practice activities of the chapters. }\end{array}$ & $\begin{array}{l}\text { - the integration } \\
\text { is not clearly } \\
\text { understood. } \\
\text { not that much }\end{array}$ \\
\hline
\end{tabular}

Additional comments: Table 1 implies that most of the respondents perceived language development skills components positively. Only a few respondents chose to comment adversely.

\section{Listening (Open ended Qs 1-7)}

TABLE 2

\begin{tabular}{|c|c|c|c|}
\hline \multirow{2}{*}{\multicolumn{2}{|c|}{ Questions }} & \multicolumn{2}{|l|}{ Responses } \\
\hline & & positive & adverse \\
\hline & $\begin{array}{l}\text { Are listening materials well recorded, as } \\
\text { authentic as possible, accompanied by } \\
\text { background information, questions and } \\
\text { activities which help comprehension? } \\
\text { write examples: chapter/s and page } \\
\text { numbers }\end{array}$ & $\begin{array}{l}\text { - } \quad \text { unit } 4 \text { p.40 language focus } 21,2 \\
\text { - } \quad \text { yes, ch\#1, page, } 8 \text {.ch\#4 page } 36 . \\
\text { - } \quad \text { eg, pg } 47 \text { ( ch } 5 \text { ),pg } 53 \text { etc } \\
\text { - } \quad \text { yes. unit 2- page } 18 / \text { ex.2.1 } \\
\text { - } \quad \text { yes. ex: students' book, chapter 2, pages } \\
\text { 18, } 19 \text { and } 22 \text { students' book, chapter } 3 \text {, } \\
\text { pages } 27,30,31 \text { and } 32\end{array}$ & $\begin{array}{l}\text { - } \quad \text { not at all. there are different } \\
\text { versions of same recordings } \\
\text { as well. } \\
\text { no, some listening tracks do } \\
\text { not match with the script. } \\
\text { chapter } 1 \text { and } 2 \text {. } \\
\text { the listening material is well } \\
\text { recorded, but it is fast so } \\
\text { students cannot understand. }\end{array}$ \\
\hline
\end{tabular}

Analysis: The above responses revealed that the majority (75\%) responded in support of the audio recordings authenticity. Only (25\%) commented adversely or hesitantly.

ii) What kind of listening material is $\bullet$ a true story (ch 2, pg 19) personal $\bullet$ no. there aren't different contained in the course? Does listening form part of dialogue conversation work? Are there specific listening passages? ? $\quad$ pg $30,3.5)$ conversations (ch 1, pg 6,1.1) write examples: chapter/s and page numbers experience (ch 2, pg 22) conversation (ch 3, etc." types of listening exercises and most of them are not clear.

- "it's both dialogue and monologue. ch\#4 • no, all the chapters. page.42"

- $\quad$ it includes conversations, students book page 16,35

Analysis: The above responses showed that the majority (90\%) named the kind of listening materials. Only (10\%) responded had adverse comments.

iii) If there are specific listening passages, $\quad \bullet \quad$ comprehension questions and taking notes what kind of activities are based on them: - $\quad$ "comprehension questions, true and false, comprehension questions, extracting - comprehension questions as well as specific specific information, etc.? write examples: chapter/s and page numbers information, eg, pg -6, 7,13 (ch 1), pg$18,19,23$ ( ch 2 ), pg $-37,41$ ( $\mathrm{ch} 4$ ) etc. extracting specific information/ unit 3 / page 27 ex. 3.2"

Analysis: The above responses showed that the majority (95\%) specified the listening passages areas. The only (5\%) comment even does show no specifications.

iv) Is the listening material set in a $\bullet \quad$ chapter 4, page 37 meaningful context? write examples: chapter/s and page numbers

- $\quad$ yes, ch\#1 page 8 ch\#5 page 47

- $\quad$ eg.pg. $47,53,37,41$ etc.

- $\quad$ yes, chapter three page 31 .

- yes, chapter 1 , page number 7 , chapter 2 , page number 19 and 22 . chapter 3 , page number 31 and 32 some of them are based on reading exercises but most of them are taken from here and there.

Analysis: The above comments revealed that the majority (75\%) viewed the listening material set in a meaningful context. However, some respondents (25\%) countered the majority as well. 


\begin{tabular}{|c|c|c|c|}
\hline & $\begin{array}{l}\text { Are there pre-listening tasks, questions, } \\
\text { etc.? } \\
\text { write examples: chapter/s and page } \\
\text { numbers }\end{array}$ & $\begin{array}{ll}\text { - } & \text { yes.ch\#3 page } 26,32 \text { ch\#12,13 } \\
\text { - } & \text { yes chapter } 2 \text { page } 19 . \\
\text { - } & \text { yes chapter } 4 \text {, page number } 42 \\
\text { - } & \text { "yes. ex: students' book, chapter } 4 \text {, page } 42 \\
& \text { "'preparation" }\end{array}$ & $\begin{array}{l}\text { - no, there aren't any. but } \\
\text { teachers provide them the } \\
\text { background of the listening } \\
\text { task. }\end{array}$ \\
\hline \multicolumn{4}{|c|}{$\begin{array}{l}\text { Analysis: The above comments revealed that the majority (65\%) confirmed to have pre-listening tasks in the textbook. However, some } \\
\text { respondents (35\%) countered the claim with a straight "no" in addition to the adverse comments. }\end{array}$} \\
\hline & $\begin{array}{l}\text { What is the recorded material on audio- } \\
\text { tracks like in terms of sound quality, } \\
\text { speed of delivery, accent, and } \\
\text { authenticity? } \\
\text { write examples: chapter/s and page } \\
\text { numbers }\end{array}$ & $\begin{array}{l}\text { - } \quad \text { ex } 1 \text { c, page } 7, \text { chapter } 1 \\
\text { - } \quad \text { ch\#1 page } 8 \text { ch\#2 page } 18 \\
\text { - } \quad \text { ound quality, chapter } 1 \text {, page number } 7 \text {, } \\
\text { chapter } 2 \text {, page number } 19, \\
\text { - overall, it is good, clear and } \\
\text { comprehensive. }\end{array}$ & $\begin{array}{l}\text { - most of them are obscure } \\
\text { and vague for the Arab } \\
\text { students in terms of quality } \\
\text { and speed. } \\
\text { - the accent is difficult, } \\
\text { - the same dialogues and } \\
\text { conversations are fast. }\end{array}$ \\
\hline \multicolumn{4}{|c|}{$\begin{array}{l}\text { Analysis: The above observations showed that the majority }(85 \%) \text { responded highlighted the audio-tracks sound quality, speed of } \\
\text { delivery, accent, and authenticity. Only few, some respondents }(15 \%) \text { countered the claim and highlighted the issues with audio-tracks. }\end{array}$} \\
\hline vii) & $\begin{array}{l}\text { Is there any video material for listening? } \\
\text { write examples: chapter/s and page } \\
\text { numbers }\end{array}$ & $\begin{array}{l}\text { - } \quad \text { yes. world culture: flashbulb memories (ch } \\
\text { 2, pg 24)" } \\
\text { - } \quad \text { yes, chapter } 4 \text { world culture page } 44\end{array}$ & $\begin{array}{l}\text { - maybe, but not in use, nor } \\
\text { we have any equipment for } \\
\text { it. } \\
\text { there's not any video } \\
\text { material for listening. }\end{array}$ \\
\hline \multicolumn{4}{|c|}{$\begin{array}{l}\text { Analysis: The above remarks are very critical and revealed that only a very limited number of respondents (20\%) stated to have video } \\
\text { material for listening. However, this claim finds no space when we look at the majority of the respondents (80\%) who countered their } \\
\text { peers. }\end{array}$} \\
\hline
\end{tabular}

Additional comments: Table 2 indicates that most of the respondents identified listening components positively except for the last question in the domain where responses are upside down.

\section{Speaking (scale Q1)}

i) How much emphasis is there on spoken English in the textbook?

\section{Speaking}

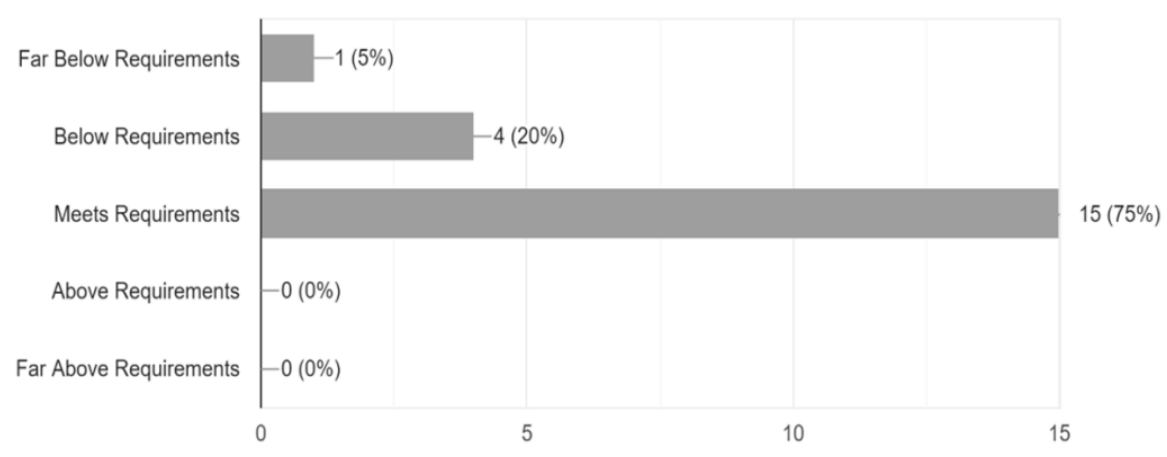

Figure 2

Figure 2 indicates that most of the participants (75\%) observed the emphasis on spoken English in the textbook and checked the "meets requirements" option. However, 5 respondents (25\%) decided to go with "below/far below requirements".

\section{Speaking (Open ended Qs 2-5)}

TABLE 3

\begin{tabular}{|c|c|c|}
\hline \multirow[t]{2}{*}{ Questions } & \multicolumn{2}{|l|}{ Responses } \\
\hline & positive & adverse \\
\hline $\begin{array}{l}\text { Wii) kind of material for speaking is } \\
\text { contained in the course? This may } \\
\text { include: oral presentation and practice of } \\
\text { language items, dialogues, role-plays, } \\
\text { communication activities (information } \\
\text { gap) } \\
\text { write examples: chapter/s and page } \\
\text { numbers }\end{array}$ & $\begin{array}{l}\text { mostly group work, oral, communication activities } \\
\text { - } \quad \text { telling stories/memories (ch 2, pg 23. 1a) } \\
\text { Role play, communicative activities, dialogues, } \\
\text { chapter3, 23 } \\
\text { "communication activities: chapter 2, page number } \\
\text { 17. chapter 1, page 14. Oral presentation: chapter } \\
\text { 2, page number 22." }\end{array}$ & $\begin{array}{llr}- & \text { "actually, speaking } \\
\text { activities are very } \\
\text { limited. } \\
\text { only a little. }\end{array}$ \\
\hline \multicolumn{3}{|c|}{$\begin{array}{l}\text { Analysis: The above statements showed that the majority (90\%) named the types of material for speaking. Only } 2 \text { respondents (10\%) } \\
\text { didn't specify anything with adverse comments. }\end{array}$} \\
\hline $\begin{array}{l}\text { iii) Are there any specific strategies for } \\
\text { conversation or other spoken activities, } \\
\text { eg debating, giving talks? } \\
\text { If yes, write chapter/s and page numbers }\end{array}$ & $\begin{array}{ll} & \text { elicitation u5 p35 task 1a,b } \\
\text { - } & \text { "yes. argument (ch } 4, \text { pg } 43,1,2,3,4) " \\
- & \text { yes, ch\# } 5 \text { page } 53 \text { ch\#7 page } 68\end{array}$ & - $\quad$ almost no \\
\hline
\end{tabular}




\begin{tabular}{|c|c|c|c|}
\hline & or write No. & $\begin{array}{l}\text { - } \quad \text { talking about topics and conversation on specific } \\
\text { topics of interest. eg- pg } 10,17,38 \text { etc } \\
\text { - } \quad \text { giving talks/ unit } 3 / \text { p. } 34 / \text { ex. } 1 . \text { a } \\
\text { giving talks and debate. chapter } 4 \text {, page } 43 \\
\end{array}$ & \\
\hline \multicolumn{4}{|c|}{$\begin{array}{l}\text { Analysis: The above responses show that only (45\%) responded named specific strategies for conversation or other spoken activities. } \\
\text { While majority (55\%) found no specific strategy in the textbook as claimed by their colleagues. }\end{array}$} \\
\hline & $\begin{array}{l}\text { Is any practice material included to help } \\
\text { learners to cope with unpredictability in } \\
\text { spoken discourse? } \\
\text { If yes, write chapter/s and page numbers } \\
\text { or write No. }\end{array}$ & $\begin{array}{ll}- & \text { u7 p } 68 \text { speaking } 1.2 \\
- & \text { "yes, chapter } 2 \text { useful language" } \\
- & \text { yes chapter } 4 \text { page } 38\end{array}$ & $\begin{array}{l}\text { - } \quad \begin{array}{l}\text { Yes, there are but all } \\
\text { of them are not useful } \\
\text { for Arab students. } \\
\text { have not come across } \\
\text { so far. }\end{array}\end{array}$ \\
\hline \multicolumn{4}{|c|}{$\begin{array}{l}\text { Analysis: The above responses reveal that only (30\%) found practice material included to help learners to cope with unpredictability in } \\
\text { spoken discourse. While majority }(70 \%) \text { discovered no materials that could help learners. }\end{array}$} \\
\hline & $\begin{array}{l}\text { Is material for spoken English (dialogues, } \\
\text { role plays, etc.) well designed to equip } \\
\text { learners for real-life interactions? } \\
\text { If yes, write chapter/s and page numbers } \\
\text { or write No. }\end{array}$ & $\begin{array}{ll}- & \text { yes, chapter } 3.34 \\
- & \text { yes, chapter }-2, \text { page-20 } \\
- & \text { yes, ch\#7 page \#68 ch \#9 page } 92 \\
-\quad & \text { yes . eg - pages - } 38,17,10 \text { etc } \\
-\quad & \text { yes/ role-plays/ unit 3/ page 34/ ex. 1.a }\end{array}$ & $\begin{array}{ll}-\quad \text { no role play and } \\
\text { dialogue is given. } \\
\text { actually a few } \\
\text { speaking activities are } \\
\text { given. I can say no. } \\
\end{array}$ \\
\hline \multicolumn{4}{|c|}{$\begin{array}{l}\text { Analysis: The above comments revealed that a big number of respondents (65\%) viewed dialogues, role plays, etc. as well designed and } \\
\text { can assist learners for real-life interactions. However, some respondents (35\%) countered the claim with "no" and adverse comments. }\end{array}$} \\
\hline
\end{tabular}

\section{Reading (Open ended Qs 1-6)}

TABLE 4

\begin{tabular}{|c|c|c|}
\hline \multirow[t]{2}{*}{ Questions } & \multicolumn{2}{|l|}{ Responses } \\
\hline & positive & adverse \\
\hline $\begin{array}{l}\text { i) Are reading passages and } \\
\text { associated activities suitable for } \\
\text { your students' levels, interests, } \\
\text { etc.? } \\
\text { write examples: chapter/s and } \\
\text { page numbers }\end{array}$ & $\begin{array}{l}\text { - yes.ch\# } 2 \text { page } 16 \text { ch\#4 page } 38,39 \\
\text { - } \quad \text { yes/ unit } 1 / \text { p. } 10 / \text { ex. } 1 \text { a- } 4 \text { a } \\
\text { - } \quad \text { yes, chapter } 4 \text {, page } 39 \\
\text { "yes they are associated with students level, interest. } \\
\text { the examples are chapter } 1 \text {, page number } 10 \text {. chapter } \\
\text { 2, page number } 16 \text { chapter } 3 \text {, page number } 29 \text { chapter } \\
\text { 4, page number } 39 \text { " }\end{array}$ & $\begin{array}{l}\text { - level is a little bit higher } \\
\text { than the students level } \\
\text { no, not at all. the students } \\
\text { do not take any interests } \\
\text { in reading skill at all. }\end{array}$ \\
\hline
\end{tabular}

Analysis: The above comments revealed that the majority (85\%) viewed reading passages and associated activities suitable for your students' levels and interests. However, the minority (15\%) felt contrary and commented adversely.

\begin{tabular}{|c|c|}
\hline $\begin{array}{l}\text { ii) Is there sufficient reading } \\
\text { material? } \\
\text { write examples: chapter/s and } \\
\text { page numbers }\end{array}$ & $\begin{array}{l}\text { - } \quad \text { yes, the secret of memory chapter } 2 \text {, page } 16 \\
\text { - } \quad \text { yes, there are . eg - pages - } 46,13,17,38 \text { etc. } \\
\text { - } \quad \text { yes chapter } 5 \text { page } 46 \text {. } \\
\text { "yes. chapter } 1 \text {, page number } 10 \text {. chapter } 2 \text {, page } \\
\text { number } 16 \text { chapter } 3 \text {, page number } 29 \text { chapter } 4 \text {, page } \\
\text { number } 39\end{array}$ \\
\hline
\end{tabular}

Analysis: The above responses for this question revealed that the majority (95\%) felt the materials provided in the textbook are sufficient. However, interestingly, 1 response (5\%) is registered as "no". introducing new language items $\bullet \quad$ "yes the reading texts contains new terms and (grammar and vocabulary), vocabulary in unit $2+4+5+6+7 "$ consolidating language work, - $\quad$ "yes, sure. ex: students' book, chapter 4, page 39 to etc.? $\quad$ introduce present perfect, past simple and present write examples: chapter/s and perfect continuous. students' book, chapter 1, page 10 page numbers

Analysis: The above comments revealed that the majority (85\%) considered reading texts used for introducing new language items consolidate language work. However, very few (15\%) still felt otherwise, not completely adverse though.

iv) Is there a focus on the $\bullet \quad$ yes, chapter 2, 16 development of reading skills - yes, chapter-4, page-39, and strategies? $\quad \bullet \quad$ ex $1 /$ page 54 /unit 5 write examples: chapter/s and $-\quad$ yes ch\#1 page $10 \mathrm{ch} \# 8$ page 50 page numbers $\quad \bullet \quad$ yes , there is . eg - pages $10,13,38,17$ etc

- $\quad$ "yes, page 17"

Analysis: The above comments revealed that a big number of respondents (60\%) viewed the development of reading skills and strategies as positive aspect of the textbook. However, 8 respondents $(40 \%)$ countered their peers with "no, not much, not at all, \& somewhat.

v) Is the reading material linked to $\bullet \bullet \quad$ yes to, speaking and writing and reading such as in unit $\bullet^{\bullet}$ somehow other skills work?
write examples: chapter/s and page numbers $\quad$ listening and reading (ch $1, \mathrm{pg} 18,1 \mathrm{a}, \mathrm{b}$, etc)"

- $\quad$ "yes, they are linked to grammar unit $2+4+5+6$ also related to vocabulary

Analysis: The above responses revealed that majority (80\%) viewed a compatibility between the reading materials and other skills. However, some respondents (20\%) countered their peers with their adverse observations.

vi) How many reading texts are $\bullet \quad$ average 2 in every chapter there, and how frequently do • in each unit 3 to 4 as unit 5 they occur? 


\begin{tabular}{|l|l|l|}
\hline $\begin{array}{l}\text { write examples: chapter/s and } \\
\text { page numbers }\end{array}$ & $\begin{array}{l}\text { "all the chapters have one or two reading texts. chapter } \\
\text { 3, page number } 35 \text { chapter 5, page number 48" } \\
\text { "for each chapter, there is one reading text. ex: students' } \\
\text { book, chapter 1, page } 10 \text { students' book, chapter 4, page } \\
39\end{array}$ & \\
\hline $\begin{array}{l}\text { Analysis: The above data revealed that all (100\%) responded positively. Interestingly, none of them provides the number of the text (as } \\
\text { the first half of the question asks exclusively). }\end{array}$ \\
\hline
\end{tabular}

Additional comments: Table 4 indicates the positive reactions to reading domain's questions. Contrary to other questions analysis, last question recorded no adverse comments.

\section{Reading (scale Qs 7-8)}

vii) How authentic/appropriate are the texts?

\section{Reading}

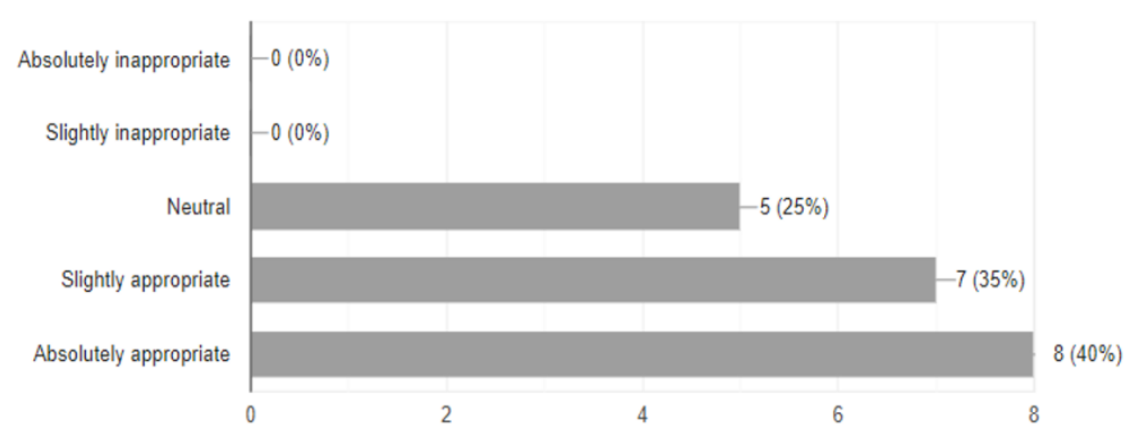

Figure 3

Figure 3 reveals that the majority (75\%) viewed the reading texts as "absolutely/slightly appropriate". While 5 respondents $(25 \%)$ decided to remain neutral and didn't go for any adverse choice.

viii) Is the subject matter appropriate (interesting, challenging, topical, varied, culturally acceptable, etc.)?

\section{Reading}

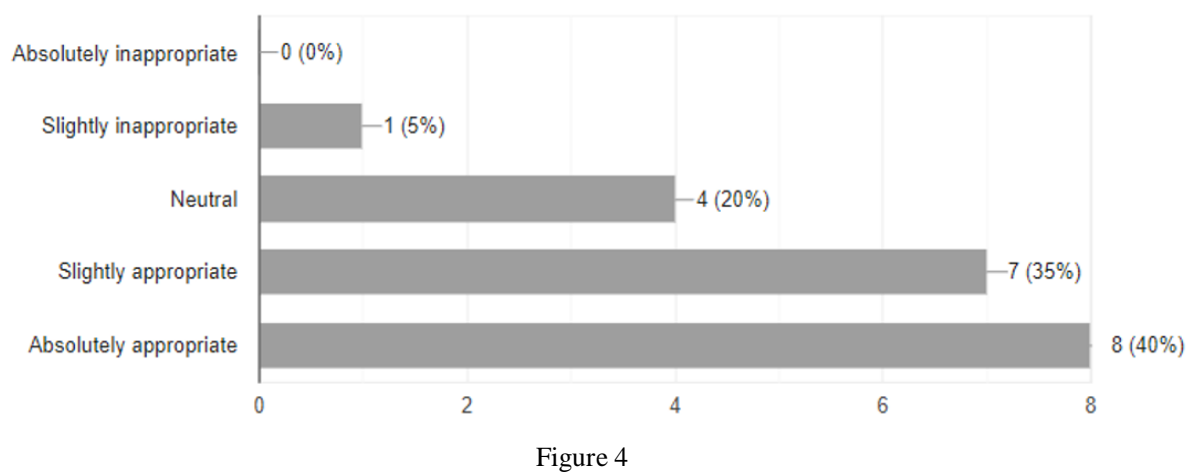

Figure 4 reveals that the majority (75\%) perceived the subject matter as "absolutely/slightly appropriate". However, 4 respondents $(20 \%)$ decided to remain neutral followed by $1(5 \%)$ who hit "slightly inappropriate".

\section{Reading (Open ended Qs 9-10)}

TABLE 5

\begin{tabular}{|c|c|c|c|}
\hline \multirow{2}{*}{\multicolumn{2}{|c|}{ Questions }} & \multicolumn{2}{|l|}{ Responses } \\
\hline & & positive & adverse \\
\hline & $\begin{array}{l}\text { Does the material help } \\
\text { comprehension by, for } \\
\text { example, setting the scene, } \\
\text { providing } \quad \text { background } \\
\text { information, giving pre-reading } \\
\text { questions? } \\
\text { write examples: chapter/s and } \\
\text { page numbers }\end{array}$ & $\begin{array}{ll} & \text { u8 p } 76 \\
- & \text { yes, chapter2, } 16 \\
\text { - } & \text { yes.ch\# } 9 \text { page } 86 \\
\text { - } & \text { yes/ unit } 1 / \text { p. } 10 / \text { ex. } 1 . a-4 . a / \\
\text { - } & \text { "yes, chapter } 3 \text { page } 28 \text { activity } 1,2,3,4 " \\
\text { - } & \text { "giving pre reading questions and providing background } \\
\text { chapter } 4 \text {, page number } 38 \\
\text { - } & \text { "yes. ex: students' book, chapter } 4, \text { page } 38 \text { students' }\end{array}$ & $\begin{array}{ll} & \text { no } \\
\text { - } & \text { sometimes }\end{array}$ \\
\hline
\end{tabular}




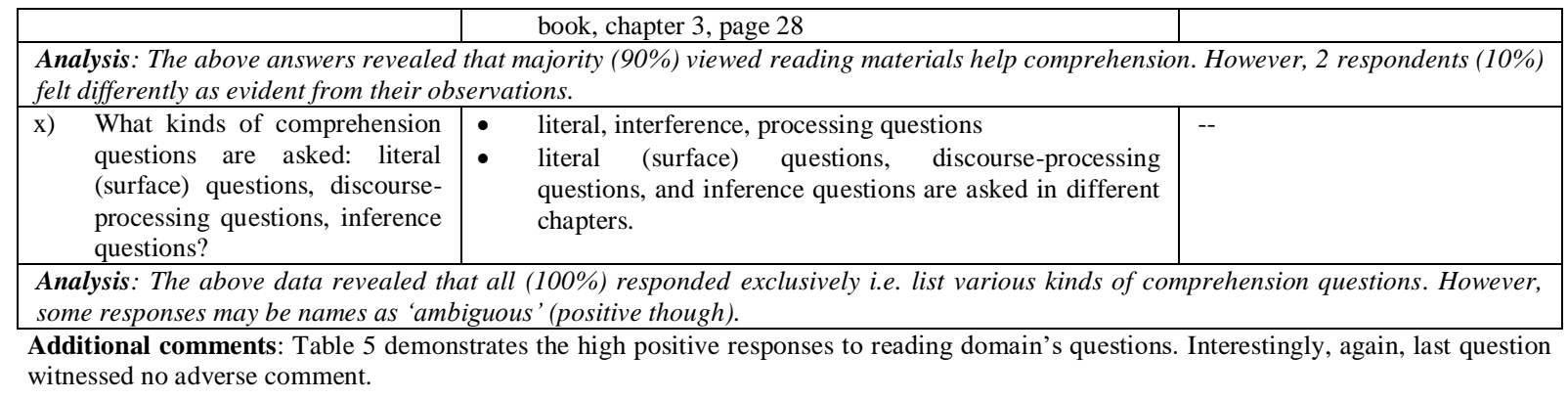

\section{Reading (scale Q11)}

xi) To what extent does the material connect learners with knowledge (knowledge of the world)?

\section{Reading}

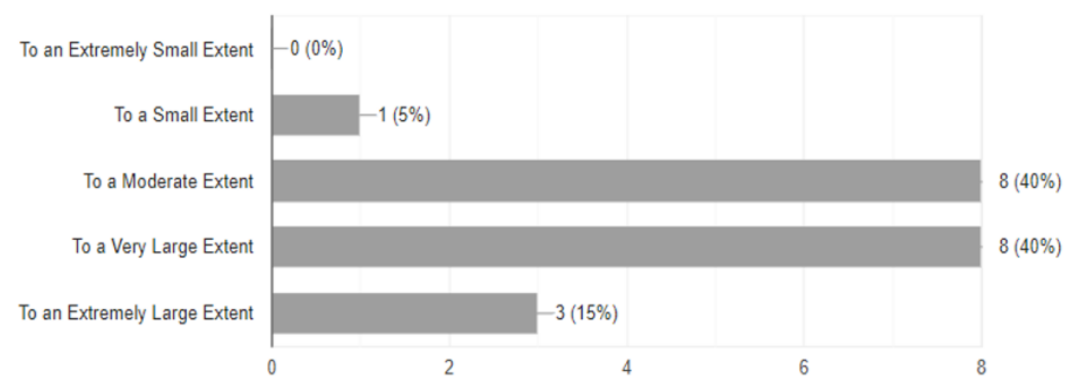

Figure 5

Figure 5 shows that the majority (95\%) perceived the materials connect (to a greater extent) learners with the knowledge of the world. However, the lone respondent (5\%) felt differently.

\section{Writing (Open ended Qs 1-5)}

\begin{tabular}{|c|c|c|c|}
\hline \multirow{2}{*}{\multicolumn{2}{|c|}{ Questions }} & \multicolumn{2}{|l|}{ Responses } \\
\hline & & positive & adverse \\
\hline & $\begin{array}{l}\text { How does the material handle } \\
\text { controlled writing, guided } \\
\text { writing and free or semi-free } \\
\text { writing? } \\
\text { Explain. }\end{array}$ & $\begin{array}{l}\text { - } \\
\text { - } \quad \text { guided writing (ch } 1, \mathrm{pg} 14,5 \mathrm{a}, \mathrm{b}, 6,7 \mathrm{a} \text { b) } \\
\text { - } \quad \text { controlled writing: correcting sentences, completion of } \\
\text { grammatical items, etc. guided writing: filling the gaps, } \\
\text { completing a paragraph according to the given information. free } \\
\text { writing: writing about any topic." } \\
\text { free and semi free writing. students are asked to write an informal } \\
\text { email (page 14), a group task of writing a cv on page } 54 \text { etc. }\end{array}$ & $\begin{array}{l}\text { there isn't any } \\
\text { format or } \\
\text { guideline on how } \\
\text { to write. }\end{array}$ \\
\hline \multicolumn{4}{|c|}{$\begin{array}{l}\text { Analysis: The (95\%) respondents for the above question stated the ways the textbook handled controlled writing, guided writing and free } \\
\text { or semi-free writing. However, very interestingly, } 1 \text { respondent }(5 \%) \text { felt "otherwise". }\end{array}$} \\
\hline & $\begin{array}{l}\text { Is there appropriate } \\
\text { progression and variety of } \\
\text { task? } \\
\text { write examples: chapter/s and } \\
\text { page numbers }\end{array}$ & $\begin{array}{ll}\text { - } & \text { u6.p59 vocab.1.2.3 } \\
\text { - } & \text { yes, chapter } 3,35 \\
\text { - } & \text { yes, ch \#1 page } 13 \text { ch\# } 2 \text { page } 23 \\
\text { - } & \text { "yes, chapter } 5 \text { page } 55 " \\
\text { - } & \text { yes/ write a travel blog/ unit } 3 / \text { p. 35/ ex. 4.a }\end{array}$ & - $\quad$ no variety of task \\
\hline \multicolumn{4}{|c|}{$\begin{array}{l}\text { Analysis: The above comments revealed that a big number of respondents (65\%) viewed the textbook appropriate as far as progression } \\
\text { and variety of writing tasks are concerned. However, some respondents (35\%) countered their peers with adverse comments. }\end{array}$} \\
\hline & $\begin{array}{l}\text { Are the conventions of } \\
\text { different sorts of writing } \\
\text { taught? If so, which ones, and } \\
\text { how are they presented? } \\
\text { write examples: chapter/s and } \\
\text { page numbers }\end{array}$ & $\begin{array}{l}\text { - } \quad \text { yes, informal letters (ch } 1, \text { pg 14) blog writing (ch } 3, \text { pg } 35) \text { story } \\
\text { writing (ch } 2, \text { pg } 15, \text { wb)" } \\
\text { "yes. guided and controlled writing .group and individual writing } \\
\text { ch\#1 page } 13 \text { ch\# } 2 \text { page } 23 \text { " } \\
\text {-yes email writing chapter } 1 \text {, page number } 14 \text { blog writing chapter } \\
\text { 2, page number } 35\end{array}$ & - $\quad$ to some extent \\
\hline \multicolumn{4}{|c|}{$\begin{array}{l}\text { Analysis: The above responses reveal that the majority (75\%) spotted the instances of the conventions of writings i.e. different sorts. } \\
\text { However, } 5 \text { respondents }(25 \%) \text { countered with adverse comments. }\end{array}$} \\
\hline & $\begin{array}{l}\text { Is there emphasis on the style } \\
\text { of written English? At an } \\
\text { appropriate level, is there } \\
\text { attention to different styles } \\
\text { according to text type? } \\
\text { write examples: chapter/s and }\end{array}$ & $\begin{array}{l}\text { - } \quad \text { yes. formal, informal, written and spoken styles. } \\
\text { - } \quad \text { yes, chapter-9 thank-you message page } 95 \\
\text { - } \quad \text { "yes email writing chapter } 1 \text {, page number } 14 \text { blog writing chapter } \\
2 \text {, page number } 35 \text { paragraph writing chapter, page number } 23 \\
\text {-yes. different styles are presented. ex: students' book, chapter } 2 \text {, } \\
\text { page } 23 \text { "'memory"". this paragraph writing. students' book, }\end{array}$ & 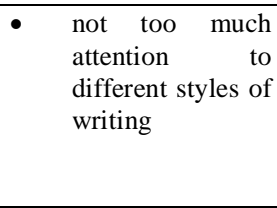 \\
\hline
\end{tabular}




\begin{tabular}{|c|c|c|}
\hline page numbers & chapter 1, page 14 ""informal e-mail". & \\
\hline \multicolumn{3}{|c|}{$\begin{array}{l}\text { Analysis: The comments revealed that a big number of respondents (65\%) responded positively and cited the references to make their } \\
\text { claim evident. However, some respondents }(35 \%) \text { countered their peers with "no". }\end{array}$} \\
\hline $\begin{array}{l}\text { v) Is attention given to the } \\
\text { language resources specific to } \\
\text { the written form, such as } \\
\text { punctuation, spelling, layout, } \\
\text { etc.? } \\
\text { If yes, explain how...? }\end{array}$ & $\begin{array}{l}\text { - yes, students' pre-knowledge of sentence structure is utilized. help } \\
\text { is also taken from technical report writing course } \\
\text { yes. students attention are drawn to the fact that sentences must } \\
\text { begin with capitals and to end with periods. }\end{array}$ & $\begin{array}{l}\text { - } \text { "in the book, } \\
\text { there is nothing } \\
\text { about } \\
\text { punctuation, } \\
\text { spelling or } \\
\text { layout. } \\
\text { no, not at all. }\end{array}$ \\
\hline \multicolumn{3}{|c|}{$\begin{array}{l}\text { Analysis: The comments for the first time reveal that the opinion is equally divided. Half of the claims cited the references to make their } \\
\text { claim evident while a similar number }(50 \%) \text { countered their peers with adverse commentary and straight "no's". }\end{array}$} \\
\hline \multicolumn{3}{|c|}{$\begin{array}{l}\text { Additional comments: Table } 6 \text { demonstrates the responses to writing domain's questions a mixed opinion, positive though. Interestingly, } \\
\text { last question witnessed claims divided among respondents as } 50 \%-50 \% \text { when asked a question: Is attention given to the language } \\
\text { resources specific to the written form, such as punctuation, spelling, lavout, etc.? }\end{array}$} \\
\hline
\end{tabular}

\section{Writing (scale Q6)}

vi) How much emphasis is there on accuracy?

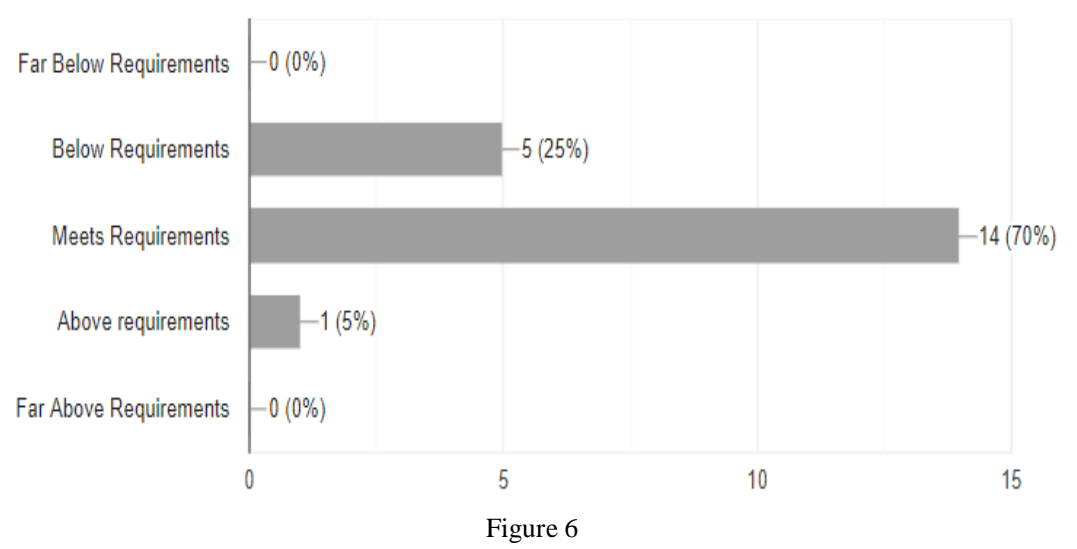

Figure 6 reveals that the majority (75\%) perceived the emphasis on accuracy under the category "meets requirements". However, 5 respondents (25\%) felt differently and decided to choose "below requirements".

\section{Writing (Open ended Qs 7-9)}

TABLE 7

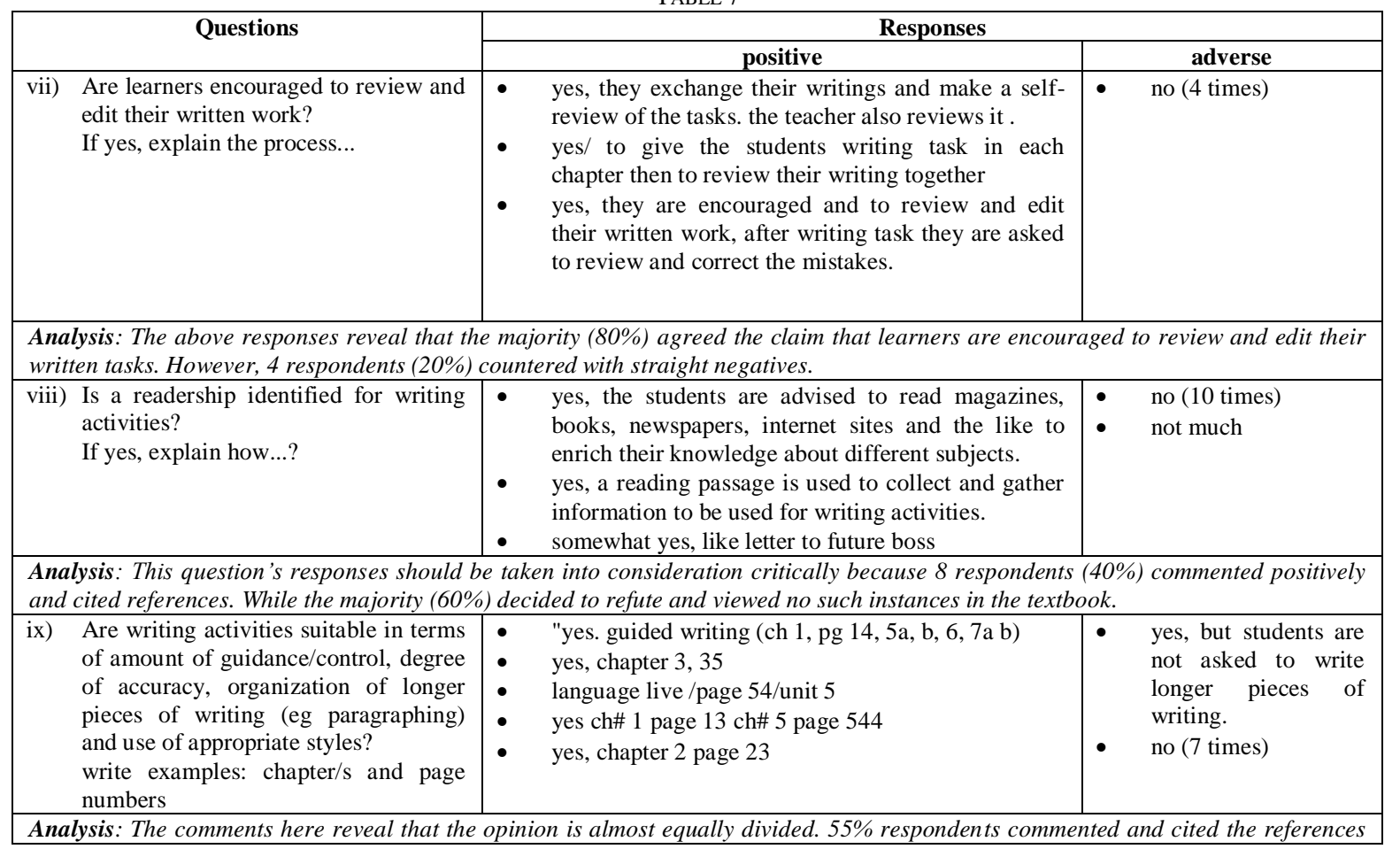


to make their claim evident while a very close number (45\%) countered their peers with adverse commentary and straight "no 's". Additional comments: Table 7 demonstrates the responses to writing domain's questions a mixed opinion. Two out of 3 questions, a critical instance in this evaluation, were perceived "adverse" as apparent from the comments.

\section{Grammar \& Vocabulary (Open ended Qs 1-2)}

TABLE 8

\begin{tabular}{|c|c|c|c|}
\hline \multirow{2}{*}{\multicolumn{2}{|c|}{ Questions }} & \multicolumn{2}{|l|}{ Responses } \\
\hline & & positive & adverse \\
\hline & $\begin{array}{l}\text { What grammar items are } \\
\text { included? Do they } \\
\text { correspond to students' } \\
\text { language needs? } \\
\text { write examples: chapter/s } \\
\text { and page numbers }\end{array}$ & $\begin{array}{l}\text { - } \quad \text { tenses reported speech comparison active and passive countable } \\
\text { and uncountable relative cluses" } \\
\text { - } \quad \text { tenses, degrees of adjectives, future clauses, ch\#1 page } 9 \mathrm{ch} \# 2 \\
\text { page } 18,19 \text { ch\# } 5 \text { page } 31 \text { " } \\
\text { formation of question, present simple, present continuous in } \\
\text { chapter } 1 \text {, past simple, past continuous, used to and would } \\
\text { chapter } 2 \text {. Yes, they correspond to each other. }\end{array}$ & - no \\
\hline \multicolumn{4}{|c|}{$\begin{array}{l}\text { Analysis: The respondents (95\%) for this question named grammar items included in the textbook and viewed that they correspond to } \\
\text { students' language needs. However, very interestingly, } 1 \text { respondent }(5 \%) \text { commented "otherwise". }\end{array}$} \\
\hline & $\begin{array}{l}\text { How are new grammar } \\
\text { items presented and } \\
\text { practiced? } \\
\text { Explain. }\end{array}$ & $\begin{array}{l}\text { - } \quad \text { through inductive and discovery methods then drills on them } \\
\text { - } \quad \text { in a cohesive manner } \\
\text { - } \quad \text { in a pragmatic way (eg page } 18 \text {, page } 6 \text { etc) } \\
\text { - drills/discussed form } \\
\text { they are presented implicitly or explicitly, and it is taught } \\
\text { inductively or deductively. }\end{array}$ & 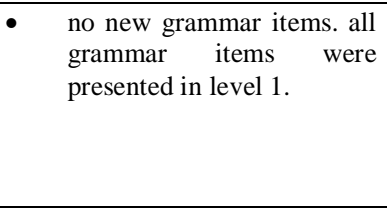 \\
\hline \multicolumn{4}{|c|}{$\begin{array}{l}\text { Analysis: The majority ( } 85 \%) \text { named the ways new grammar items presented and practiced. However, very few, } 3 \text { respondent (15\%) } \\
\text { countered the majority's claim with adverse commentary. }\end{array}$} \\
\hline
\end{tabular}

\section{Grammar \& Vocabulary (scale Q3)}

iii)To what extent is the presentation and practice: related to what learners, already know and to what has already been taught, appropriately controlled \& organized, representative of the grammar rule to be learned, relevant to learners' needs and interests?

\section{Grammar \& Vocabulary}

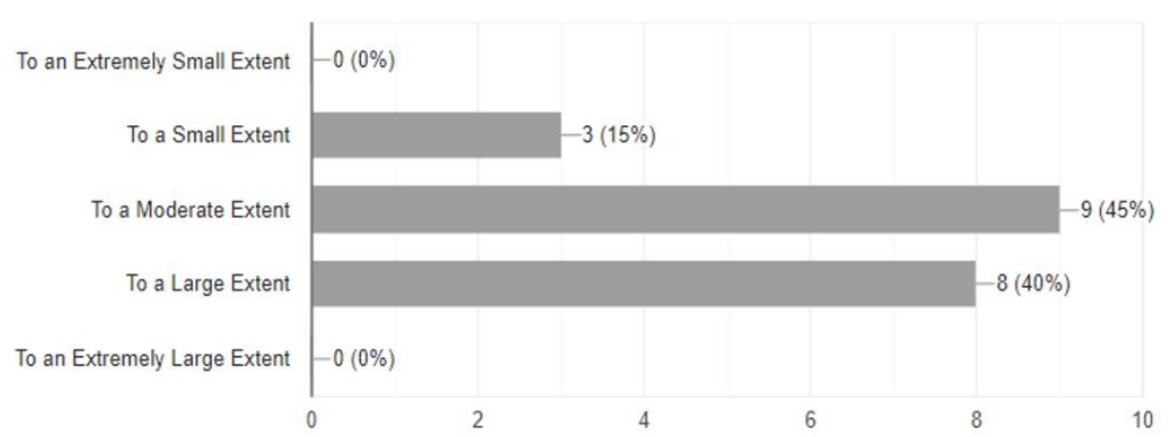

Figure 7

Figure 7 reveals that the majority (85\%) perceived the presentation and practice relevant to learners' needs and interests. However, 3 respondents (15\%) felt differently and chose "to a small extent".

\section{Grammar \& Vocabulary (Open ended Qs 4-6)}

TABLE 9

\begin{tabular}{|c|c|c|c|}
\hline \multirow{2}{*}{\multicolumn{2}{|c|}{ Questions }} & \multicolumn{2}{|c|}{ Responses } \\
\hline & & positive & adverse \\
\hline & $\begin{array}{l}\text { Are they (grammar items) } \\
\text { presented in small units for } \\
\text { easy learning? } \\
\text { write examples: chapter/s and } \\
\text { page numbers }\end{array}$ & $\begin{array}{ll}- & \text { unit } 5 \text { p43 grammar } 1.2 \\
- & \text { yes, chapter } 2,18 \\
- & \text { ex } 1,2 \text { (grammar page } 49 \text { ) unit } 5 \\
\text { - } & \text { yes, ch\#1 page } 6,9 \text { ch\#2 page } 18,19 \\
- & \text { yes . eg - pages - } 6,18 \text { etc. } \\
\text { - } & \text { "yes, chapter } 1 \text { page } 9 "\end{array}$ & $\begin{array}{l}\text { they are presented in a } \\
\text { small and confusing } \\
\text { manner without } \\
\text { adequate explanations } \\
\text { of the grammar rule. } \\
\text { small units, but scanty. }\end{array}$ \\
\hline \multicolumn{4}{|c|}{$\begin{array}{l}\text { Analysis: The majority }(80 \%) \text { cited the references for grammar items presented in small units for easy learning. However, } 4 \text { respondent } \\
(20 \%) \text { countered the majority's claim with adverse comments. }\end{array}$} \\
\hline & $\begin{array}{l}\text { Is there an emphasis on } \\
\text { language form? } \\
\text { write examples: chapter/s and }\end{array}$ & $\begin{array}{ll}- & \text { yes, chapter } 1,6 \\
- & \text { ex } 1 \text { (practice) unit } 5 \text {,page } 49\end{array}$ & $\begin{array}{ll} & \text { not much } \\
- & \text { sometimes }\end{array}$ \\
\hline
\end{tabular}




\begin{tabular}{|c|c|c|c|}
\hline & page numbers & $\begin{array}{l}\text { - } \quad \text { yes.ch\#5 page } 53 \\
\text { - } \quad \text { "yes. unit-4/ p. } 41 \text { / ex. } 1 / \\
\text { - } \quad \text { yes, chapter two page } 20 . \\
\text { - } \quad \text { "yes chapter } 1 \text {, page } 6 \text { chapter } 3 \text {, page } 18 \\
\text { - } \quad \text { "yes. ex: students' book, chapter } 1 \text {, page } 6 \text { students' book, } \\
\text { chapter 2, page } 18\end{array}$ & \\
\hline \multicolumn{4}{|c|}{$\begin{array}{l}\text { Analysis: The majority (85\%) cited the references to support their views i.e. emphasis on language form as evident from the comments. } \\
\text { However, } 3 \text { respondent (15\%), as per the comments, didn't find any such instances. }\end{array}$} \\
\hline & $\begin{array}{l}\text { Is there an emphasis on } \\
\text { language use (meaning)? } \\
\text { write examples: chapter/s and } \\
\text { page numbers }\end{array}$ & $\begin{array}{l}\text { - } \quad \text { yes, chapter } 3,35 \\
\text { - } \quad \text { unit } 5 \text { page } 23 \text { ex } 3 \text { workbook } \\
\text { - } \quad \text { yes ch\# } 9 \text { page } 87 \\
\text { - } \quad \text { yes. unit } 1 / \text { p. } 9 / \text { ex. b/ present simple and present } \\
\text { continuous } \\
\text { - } \quad \text { yes chapter } 2 \text { pages } 20,21 " \\
\text { - yes, chapter three page } 35 .\end{array}$ & $\begin{array}{ll}- & \text { no }(3 \text { times }) \\
\text { - } & \text { not much }\end{array}$ \\
\hline \multicolumn{4}{|c|}{$\begin{array}{l}\text { Analysis: The majority of the respondents }(80 \%) \text { referenced their views i.e. emphasis on language use as evident from their comments. } \\
\text { However, } 4 \text { responses }(20 \%) \text {, as evident from the comments, viewed the question adversely. }\end{array}$} \\
\hline
\end{tabular}

Grammar \& Vocabulary (scale Q7)

vii) How balanced is the treatment of form and use?

\section{Grammar \& Vocabulary}

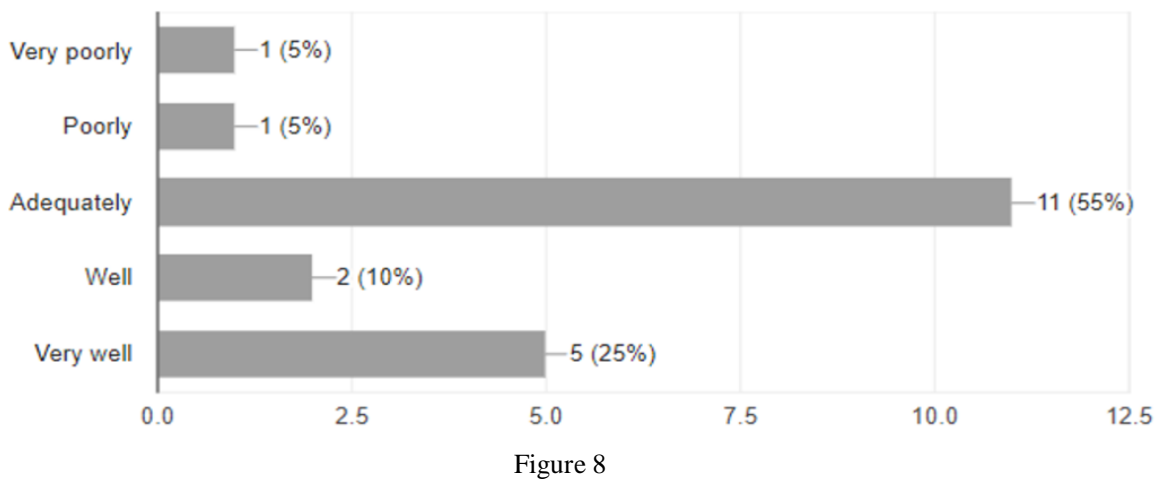

Figure 8 shows that the majority (90\%) perceived the treatment of form and use as balanced. However, 2 respondents (10\%) felt differently and viewed as "poorly/very poorly".

\section{Grammar \& Vocabulary (Open ended Qs 8-16)}

\begin{tabular}{|c|c|c|}
\hline \multirow[t]{2}{*}{ Questions } & \multicolumn{2}{|l|}{ Responses } \\
\hline & $\begin{aligned} & \text { positive } \\
&\end{aligned}$ & adverse \\
\hline $\begin{array}{l}\text { viii) Are newly introduced items } \\
\text { related to and contrasted } \\
\text { with items already familiar } \\
\text { to the learners? } \\
\text { write examples: chapter/s } \\
\text { and page numbers }\end{array}$ & $\begin{array}{l}\text { - } \quad \text { unit } 4 \text { page } 42 \text { ex } 2 \text { a } \\
\text { - } \quad \text { yes, ch\#1 page } 6,9 \text { ch\#2 page } 18,21 \\
\text { - } \quad \text { yes, they move from the familiar to the unknown. } \\
\text { - } \quad \text { "yes, chapter } 4 \text { page " } \\
\text { - } \quad \text { yes, chapter } 1,2,34,5 \text { and } 6 \\
\text { - } \quad \text { "yes they are related to the students pre knowledge unit } 1 \\
\text { present simple page } 9 \text { unit } 2 \text { past forms page } 18 \text { " }\end{array}$ & $\begin{array}{l}\text { - } \quad \text { actually, there are no } \\
\text { new items. students are } \\
\text { familiar with the given } \\
\text { items because they } \\
\text { have been taught these } \\
\text { items in level } 1 . \\
\text { - } \\
\text { to some extent } \\
\text { somewhat as matter of } \\
\text { opinion }\end{array}$ \\
\hline \multicolumn{3}{|c|}{$\begin{array}{l}\text { Analysis: The comments revealed that majority (60\%) cited the references in terms of newly introduced items related to and contrasted } \\
\text { with items already familiar to the learners. However, a good number of respondents }(40 \%) \text { countered their peers with no and adverse } \\
\text { comments. }\end{array}$} \\
\hline $\begin{array}{l}\text { Where one grammatical } \\
\text { form has more than one } \\
\text { meaning, are all relevant } \\
\text { meanings taught (not } \\
\text { necessarily together)? } \\
\text { write examples: chapter/s } \\
\text { and page numbers }\end{array}$ & $\begin{array}{l}\text { - } \quad \text { "future forms u5 p49 grammar 1.2" } \\
\text { "yes. use of present continuous for actions happening at this } \\
\text { moment, in the present period, as temporary, for gradual } \\
\text { changing) ch 1,pg } 9 " \\
\text { - } \quad \text { "i used to play football. i would play football. chapter 2, 20" } \\
\text { - yes, unit } 3 \text { page } 30 \\
\text { - } \quad \text { "yes, chapter } 1 \text { page 9" } \\
\text { chapter five e.g present continuous for future. }\end{array}$ & $\begin{array}{ll}- & \text { No }(2 \text { times }) \\
- & \text { not (so far })\end{array}$ \\
\hline \multicolumn{3}{|c|}{$\begin{array}{l}\text { Analysis: Most of the respondents (80\%) referenced their views and commented positively. However, } 4 \text { responses (20\%), as evident } \\
\text { from the responses, commented adversely. }\end{array}$} \\
\hline
\end{tabular}




\begin{tabular}{|c|c|c|c|}
\hline & $\begin{array}{l}\text { Is material for vocabulary } \\
\text { teaching adequate in terms } \\
\text { of quantity and range of } \\
\text { vocabulary, emphasis placed } \\
\text { on vocabulary development, } \\
\text { strategies for individual } \\
\text { learning? } \\
\text { write examples: chapter/s } \\
\text { and page numbers }\end{array}$ & $\begin{array}{ll} & \text { yes, chapter } 2,21 \\
- & \text { unit } 1, \text { page } 11,3 \text { and } 1 \mathrm{a} \\
\text { - } & \text { yes, ch\# } 4 \text { page } 40 \text { ch\# } 5 \text { page } 49 \\
\text { - } \quad \text { yes . for eg pages - } 21,40,8,47 \text { etc } \\
\text { - } \quad \text { yes, chapter } 1,2,3 \text { and } 4 . \\
\quad \text { yes. ex: students' book, chapter 2, page } 16 \text { and } 21 \text { students' } \\
\quad \text { book, chapter } 3 \text {, page } 26 \text { and } 28\end{array}$ & $\begin{array}{ll}- & \text { not much } \\
- & \text { higher in level for most } \\
\text { students }\end{array}$ \\
\hline \multicolumn{4}{|c|}{$\begin{array}{l}\text { Analysis: Most of the respondents }(70 \%) \text { commented positively in support of materials for teaching vocabulary. However, } 6 \text { responses } \\
(30 \%) \text {, as evident from the comments, countered negatively. }\end{array}$} \\
\hline & $\begin{array}{l}\text { How is new vocabulary } \\
\text { presented? } \\
\text { List. }\end{array}$ & $\begin{array}{ll}\text { - } & \text { in word list and in text } \\
\text { - } & \text { nicely presented } \\
\text { - } & \text { word lists, in context, with visuals } \\
\text { - } & \text { different techniques are used } \\
\text { - } & \text { in context } \\
\end{array}$ & $\begin{array}{ll}\text { - } & \text { ruthless egotistical }\end{array}$ \\
\hline \multicolumn{4}{|c|}{$\begin{array}{l}\text { Analysis: The respondents (95\%) for this question enlisted the new vocabulary presented in the textbook. However, very interestingly, } 1 \\
\text { respondent (5\%) commented with "ruthless egotistical", which, for the researcher, remains a "puzzle". }\end{array}$} \\
\hline xii) & $\begin{array}{l}\text { How is the meaning of new } \\
\text { vocabulary taught? } \\
\text { Explain... }\end{array}$ & $\begin{array}{l}\text { - } \quad \text { drills and in context } \\
\text { giving the students short definition, remind them to situations } \\
\text { and pictures relate to vocabulary. } \\
\text { - } \quad \text { Eliciting and inference. } \\
\text { through word-family and structure } \\
\text { - Through giving sentences in different context } \\
\text { - In a table of words, text, guessing meanings etc } \\
\text { to understand the meaning from the context/ using English- } \\
\text { English dictionary. } \\
\text { By explanation in context, miming, pictures } \\
\text { in text and in listening, by playing the audio and giving } \\
\text { exercise which answers are the main words in a unit. }\end{array}$ & -- \\
\hline \multicolumn{4}{|c|}{$\begin{array}{l}\text { Analysis: The responses reveal that all respondents (100\%) commented the ways, as evident from the comments, in which the meaning } \\
\text { of new vocabulary taught. }\end{array}$} \\
\hline & $\begin{array}{l}\text { Is there any distinction } \\
\text { between active and passive } \\
\text { vocabulary? } \\
\text { write examples: chapter/s } \\
\text { and page numbers }\end{array}$ & $\begin{array}{ll} & \text { unit } 5, \text { page } 59, \text { ex } 2 \\
- & \text { yes, ch\#7 page } 69 \\
- & \text { "yes, chapter } 1 \text { page } 11 "\end{array}$ & $\begin{array}{l}\text { - } \quad \text { not all verbs used in } \\
\text { active can be used with } \\
\text { the passive u.7 p } 69 \\
\text { grammar" } \\
\text { not aware of that }\end{array}$ \\
\hline \multicolumn{4}{|c|}{$\begin{array}{l}\text { Analysis: The above remarks are very critical and revealed that only a very limited number of respondents (35\%) viewed any distinction } \\
\text { between active and passive vocabulary. However, this claim struggles when we look at the respondents who contribute as majority } \\
(65 \%) \text { and adversely commented as evident from the responses. }\end{array}$} \\
\hline xiv) & $\begin{array}{l}\text { Is vocabulary presented in a } \\
\text { structured, purposeful way? } \\
\text { write examples: chapter/s } \\
\text { and page numbers }\end{array}$ & 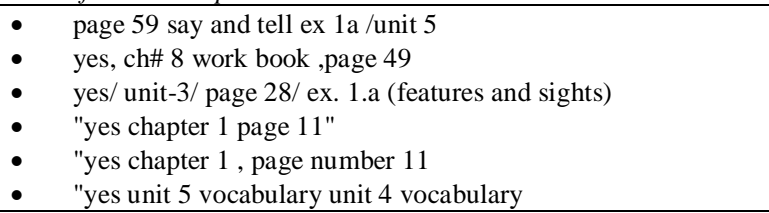 & $\begin{array}{ll}- & \text { not much } \\
- & \text { sometimes }\end{array}$ \\
\hline \multicolumn{4}{|c|}{$\begin{array}{l}\text { Analysis: Most of the respondents (85\%) referenced the instances where the vocabulary presented in a structured, purposeful way. } \\
\text { However, } 3 \text { responses (15\%), as evident from the responses, commented adversely. }\end{array}$} \\
\hline $\mathrm{xv})$ & $\begin{array}{l}\text { Are learners sensitized to the } \\
\text { structure of the lexicon } \\
\text { through vocabulary-learning } \\
\text { exercises based on semantic } \\
\text { relationships, formal } \\
\text { relationships, collocations or } \\
\text { situation-based word } \\
\text { groups? } \\
\text { write examples: chapter/s } \\
\text { and page numbers }\end{array}$ & $\begin{array}{ll}- & \text { chapter, } 3 \text {, work, } 17 \\
\text { - } & \text { unit } 5 / \text { word group ex } 1 \text { page } 28 \\
\text { - } & \text { yes, ch\# } 5 \text { page } 49 \\
& \text { yes . eg pages }-8,21,40,47 \text { etc }\end{array}$ & $\begin{array}{ll} & \text { no }(6 \text { times }) \\
& \text { not much }\end{array}$ \\
\hline \multicolumn{4}{|c|}{$\begin{array}{l}\text { Analysis: Most of the respondents (65\%) agreed that the learners sensitized to the structure of the lexicon through vocabulary-learning } \\
\text { exercises. However, } 7 \text { responses (35\%), as evident from the comments, countered negatively. }\end{array}$} \\
\hline & $\begin{array}{l}\text { Does the material enable } \\
\text { students to expand their own } \\
\text { vocabulary independently by } \\
\text { helping them to develop } \\
\text { their own learning } \\
\text { strategies? } \\
\text { If yes, explain the process.... }\end{array}$ & $\begin{array}{l}-\quad \text { yes u5 p } 49 \text { vocab.2a } \\
-\quad \text { "yes chapter } 1 \text { page } 11 " \\
\text { - } \quad \text { yes , chapter four page } 40 .\end{array}$ & $\begin{array}{l}\text { - } \text { no. they don't use the } \\
\text { new vocabulary in } \\
\text { speaking or writing. } \\
\text { they use limited and } \\
\text { easier vocabulary. } \\
\text { - not so often }\end{array}$ \\
\hline & 1 & $n$ & vocabulary independently. \\
\hline
\end{tabular}




\section{Style \& Appropriacy (Open ended Qs 1-5)}

TABLE 11

\begin{tabular}{|c|c|c|c|}
\hline \multirow{2}{*}{\multicolumn{2}{|c|}{ Questions }} & \multicolumn{2}{|l|}{ Responses } \\
\hline & & positive & adverse \\
\hline & $\begin{array}{l}\text { Are style and appropriacy dealt with? If so, is } \\
\text { language style matched to social situation? } \\
\text { write examples: chapter/s and page numbers }\end{array}$ & $\begin{array}{ll}- & \text { u5 p32,11a } \\
- & \text { yes, chapter } 3,30 \\
\text { - } & \text { unit 2, page } 22 \text { ex } 2,3 \\
- & \text { ch\# 4 page } 40\end{array}$ & $\begin{array}{ll}- & \text { no }(5 \text { times }) \\
- & \operatorname{not} \text { much }(2 \text { times })\end{array}$ \\
\hline \multicolumn{4}{|c|}{$\begin{array}{l}\text { Analysis: Most of the respondents (65\%) agreed the question's framework and cited the references where they felt that style and } \\
\text { appropriacy go hand-in-hand. However, } 7 \text { responses (35\%), as evident from the comments, countered negatively. }\end{array}$} \\
\hline & $\begin{array}{l}\text { Is appropriacy taught with reference to choice of } \\
\text { grammar, vocabulary, discourse structure or } \\
\text { pronunciation? } \\
\text { e examples: chapter/s and page numbers }\end{array}$ & $\begin{array}{ll}- & \text { u6 p } 56 \text { a twist of fate: } 2 \\
- & \text { unit } 2 \text { page } 19,20 \\
- & \text { yes, ch\# } 2 \text { page } 19 \\
- & \text { "yes, chapter } 2, \text { page } 22 \text { and } 23 "\end{array}$ & $\begin{array}{ll}- & \text { no }(3 \text { times }) \\
- & \text { sometimes }\end{array}$ \\
\hline \multicolumn{4}{|c|}{$\begin{array}{l}\text { Analysis: Most of the respondents (80\%) cited the references where they felt that appropriacy taught with reference to grammar, } \\
\text { vocabulary, discourse structure or pronunciation. However, some comments (20\%), as evident from the responses, countered negatively. }\end{array}$} \\
\hline & $\begin{array}{l}\text { Does the textbook identify situations or areas of } \\
\text { language use where learners should be } \\
\text { particularly sensitive to using appropriate styles, } \\
\text { e.g. when requesting/complaining? } \\
\text { write examples: chapter/s and page numbers }\end{array}$ & $\begin{array}{ll}\text { - } & \text { u5 p53 useful language } \\
\text { - } & \text { unit 3, task page } 34, \text { ex } 2,3,4 \\
\text { - } & \text { yes, ch\#4 page } 39 \\
\text { - } & \text { "yes, chapter } 4 \text { page } 41 "\end{array}$ & $\begin{array}{ll}- & \text { not much } \\
- & \text { no, not at all. }\end{array}$ \\
\hline \multicolumn{4}{|c|}{$\begin{array}{l}\text { Analysis: Most of the respondents ( } 60 \%) \text { agreed the question's idea and cited the references where learners should be particularly } \\
\text { sensitive to using appropriate styles. However, } 8 \text { responses (40\%), as evident from the comments, countered the former group with a } \\
\text { straight "no". }\end{array}$} \\
\hline & $\begin{array}{l}\text { Are learners led towards an understanding of } \\
\text { why some forms in English are more formal } \\
\text { than others? } \\
\text { write examples: chapter/s and page numbers }\end{array}$ & $\begin{array}{l}\text { - } \quad \text { "u5 p53 useful language u5 p33 writing } \\
\text { - } \quad \text { yes, chapter } 2,21 \\
\text { - } \quad \text { yes ( } 2 \text { times) } \\
\text { - } \quad \text { ex } 2 \text { b /page } 54 \text { /unit } 5 \\
\text { - yes ch\#5 work book pages } 32,33 \\
\text { - yes, for example we teach them how to } \\
\text { write a cv in unit 5, and which is why } \\
\text { there is a need to teach formal and } \\
\text { informal language forms. }\end{array}$ & $\begin{array}{l}\text { - } \quad \text { to some extent. } \\
\text { - } \quad \text { not much } \\
\text { - }\end{array}$ \\
\hline \multicolumn{4}{|c|}{$\begin{array}{l}\text { Analysis: The comments for the first the second time in this study reveal that the opinion is equally divided. Half of the claims (50\%) } \\
\text { cited the references and commented to make their claim evident while a similar percentage (50\%) countered their peers with adverse } \\
\text { responses. }\end{array}$} \\
\hline & $\begin{array}{l}\text { Are any other aspects of style other than } \\
\text { formal/informal included (e.g. register }- \text { the } \\
\text { language used within a particular activity or } \\
\text { occupation)? } \\
\text { write examples: chapter/s and page numbers }\end{array}$ & $\begin{array}{ll}- & \text { blogs u3 p } 35 \\
\text { - } & \text { unit } 1, \text { page } 10 \text {,ex } 2 \mathrm{a} \\
\text { - } & \text { yes, ch\#7 page } 68 \\
\text { - } & \text { yes. there are various ESP specific } \\
\text { segments in the text which caters to } \\
\text { activity or occupation. }\end{array}$ & $\begin{array}{ll}- & \text { no }(11 \text { times }) \\
\text { - } & \text { not much }\end{array}$ \\
\hline \multicolumn{4}{|c|}{$\begin{array}{l}\text { Analysis: The remarks are very critical and revealed that only } 6 \text { respondents (30\%) viewed other aspects of style other than } \\
\text { formal/informal included in the textbook. However, this claim battles when we glance the respondents who contribute as majority (70\%) } \\
\text { and commented in negatives as evident from the responses. }\end{array}$} \\
\hline
\end{tabular}

Additional comments: Table 11 categorizes style \& appropriacy domain's questions as mixed responses. All comments were ranged between $80 \%-30 \%$ for the positive end and swinged between $20 \%-70 \%$ to the adverse end.

\section{CONCLUSION}

This study evaluated the contents of Cutting Edge. It looked at the textbook's positive and adverse attributes and discovered that the positive aspects vastly exceeded the negative ones. Despite some flaws in the textbook like lack of video material, lack of specific strategies for conversation, and almost no distinction between active and passive vocabulary, the teachers (for the most parts) thought that the textbook contents were appropriate. However, the researcher, based on the adverse comments, suggests that a latest EFL commercial textbook or series be reviewed which, potentially, will cover the space. It is hoped that EFL teachers will discover more on how to examine a textbook in terms of language development skills, listening, speaking, reading, writing, grammar \& vocabulary, and style \& appropriacy.

\section{RECOMMENDATION}

This study recommends developing authentic materials that are tailored to the needs and interests of the learners. To meet the learning outcomes, the social and cultural context must be considered when developing materials. The materials should be tested for at least one semester to get input from teachers and students, then reviewed by the professionals in the field of syllabus design and materials development. Before the execution, incorporate the feedback and expert comments. 


\section{REFERENCES}

[1] Abbasian, R., \& Khajavi, Y. (2011). English Language Teaching, National Identity and Globalization in Iran: the Case of Public Schools. International Journal of Humanities and Social Science, 1(10), 181-186.

[2] Ahour, T., Towhidiyan, B., \& Saedi, M. (2014). The evaluation of "English textbook 2" taught in Iranian high schools from teachers' perspectives. English Language Teaching, 7(3), 150-158. doi:10.5539/elt.v7n3p150

[3] Birjandi, P. \& Alizadeh, I. (2012). Manifestation of critical thinking skills in the English textbooks employed by language institutes in Iran. International Journal of Research studies in Language Learning, 3(1), 11-23.

[4] Byrd, P. (2001). Textbooks: Evaluation and selection and analysis for implementation. In Celce-Murcia, M. (Ed.) Teaching English as a second or foreign language, 3rd ed. Boston: Heinle \& Heinle.

[5] Byrd, P., \& Schuemann, C. (2014). English as a second/foreign language textbooks: How to choose them-how to use them. In M. Celce-Murica, D. Brinton, \& M. A. Snow (Eds.), Teaching English as a second or foreign language (pp. 380-393). Boston, MA: National Geographic Learning.

[6] Crawford, J. (2002). The Role of Materials in the Language Classroom: Finding the Balance. In J. Richards \& W. Renandya. Methodology in Language Teaching: An Anthology of Current Practice. Cambridge: Cambridge University Press.

[7] Cunningsworth, A. (1995). Choosing your coursebook. Oxford: Macmillan Education.

[8] Daoud, A.M. \& Celce-Murcia, M. (1979). Selecting and evaluating textbooks. In Celce-Murcia, M. \& McIntosh, L. (Eds.) Teaching English as a second or foreign language. New York: Newbury House.

[9] Fredriksson, C. and Olsson R. (2006). English Textbook Evaluation: An Investigation into Criteria for Selecting English Textbooks. Unpublished Master Thesis, Malmo University.

[10] Garinger, D. (2002). Textbook selection for the ESL classroom. ERIC Clearinghouse on Languages and Linguistics. $\begin{array}{lllll}\text { Washington, } & \text { DC. } & \text { Rugust } & \text { 27, } & \text { 2021, }\end{array}$ https://citeseerx.ist.psu.edu/viewdoc/download?doi=10.1.1.507.8175\&rep=rep1\&type=pdf

[11] Ghorbani, M. R. (2011). Quantification and Graphic Representation of EFL Textbook Evaluation Results. Theory and Practice in Language Studies, 1 (5), p.511-520.

[12] Hussin, N. I. S. M., Nimehchisalem, V., \& Kalajahi, S. A. R. (2016). Evaluating the presentation of new vocabulary items in Malaysian form three English language textbook. Malaysian Journal of Language and Linguistics, 5 (1), 60-78

[13] Littlejohn, A. (1998) The analysis of language teaching materials. In B. Tomlinson (Ed.), Materials development in language teaching (pp. 190-216). Cambridge: Cambridge University Press.

[14] Mann, S. \& Copland, F. (2015). Materials Development. Washington D.C.: TESOL Press.

[15] McDonough, J. and Shaw, C. (2003). Materials and Methods in ELT: A Teacher's Guide. 2nd edition. Oxford: Blackwell Publishing.

[16] Mukundan, J., \& Ahour, T. (2010). A review of textbook evaluation checklists across four decades (1970-2008) (pp. 336-352). In B. Tomlinson \& Masuhara, H. (eds.) Research for Materials Development in Language Learning: Evidence for Best Practice. London: Continuum

[17] Nunan, David. (1991). Language Teaching Methodology A textbook for teachers. Hemel Hempstead: Prentice Hall.

[18] Rashidi, N., \& Kehtarfard, R. (2014). A need analysis approach to the evaluation of Iranian third-grade high school English textbook. SAGE, 1-9. doi:10.1177/2158244014551709

[19] Riasati, M. J. and Zare, P. (2010). „Textbook evaluation: EFL teacher's perspectives on new Interchange ${ }^{e}$. Studies in Literature and Language, 1(8): 54-60.

[20] Richards, J. (2001). Curriculum Development in Language Teaching. Cambridge: Cambridge University Press.

[21] Sarem, S. N., Hamidi, H., \& Mahmoudie, R. (2013). A critical look at textbook evaluation: a case study of evaluating an ESP course-book: English for international tourism. International Research Journal of Applied and Basic Science (IRJABS), 4(2), 372-380

[22] Sheldon, L. (1988). Evaluating ELT Textbooks and Material. ELT Journal, Volume 42, Issue 4, 237-246.

[23] Tomlinson, B. (1998). Materials Development in Language Teaching. Cambridge: Cambridge University Press.

[24] Yasemin, K. (2009). Evaluating the English textbooks for young learners of English at Turkish primary education. Procedia Social and Behavioral Sciences, 1(1), 79-83

Mohd Nazim earned his Ph.D. in English (Literary Stylistics) from Aligarh Muslim University, India in 2008. He earned his master's degree in English Language Teaching, also from AMU, in 2002. A post graduate diploma in Linguistics enriches his academic qualifications further. He has been teaching a variety of English language and literature courses for more than 13 years.

$\mathrm{He}$ is currently an Associate Professor in the Department of English at Najran University, Saudi Arabia. His research interests include (but not limited to) developing writing skills, assessment literacy, teacher training, and ethical interpretation of literature.

Dr. Nazim has rich experience in journal editorial services, and currently sits on the editorial board of English Language Teaching journal, published by Canadian Center of Science and Education. 